\title{
UNPUBLISHED STELA OF TJJ AT CAIRO MUSEUM (C.G. 10232)
}

\section{Mostafa SHALABY ${ }^{1}$ and Mohamed NASSAR ${ }^{2}$}

\author{
${ }^{1}$ Associate Professor, Faculty of Education, Ain Shams University, Egypt \\ E-mail: mostafa.shalaby@utoronto.ca \\ ${ }^{2}$ Lecturer, Faculty of Archaeology, Fayoum University, Egypt \\ E-mail: man00@fayoum.edu.eg
}

\begin{abstract}
This paper aims to publish small rectangular round topped stela belonging to Ijj. This stela is in Cairo Museum under number (C.G. 10232, T.N R 26.4.22.7). The stela mentions the family genealogy and a short offering formula. The names, decorations, and the orthography of the names and an offering formula dated it to the first half of the Thirteenth Dynasty.
\end{abstract}

\section{KEYWORDS}

Stela, Thirteenth Dynasty, 'Ijj, Family genealogy.

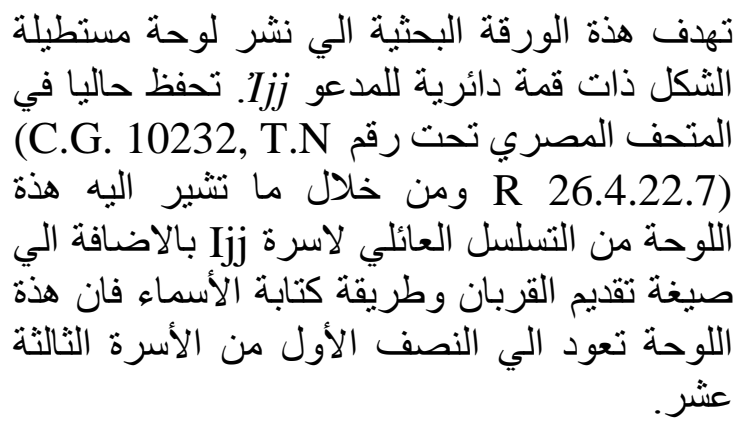

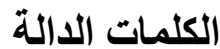

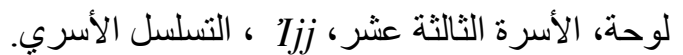

\section{DESCRIPTION}

The stela is made of limestone with no traces of colors. It has a ruffle rectangle shape with a round top. Its measurements C. $34 \mathrm{~cm}$ in height, C. $21 \mathrm{~cm}$ in width and the sickness between $10 \mathrm{~cm}$ to $12 \mathrm{~cm}$. Its provenance is unknown but probably come from Abydos. The stela is divided into three registers of incised sunk reliefs and inscriptions. The first section contains the main texts which include nine vertical lines; the hieroglyphic text occupies the round top of the stela in two levels. There are some scratches and damages at the top and edges of the stela erasing some signs of the texts. 


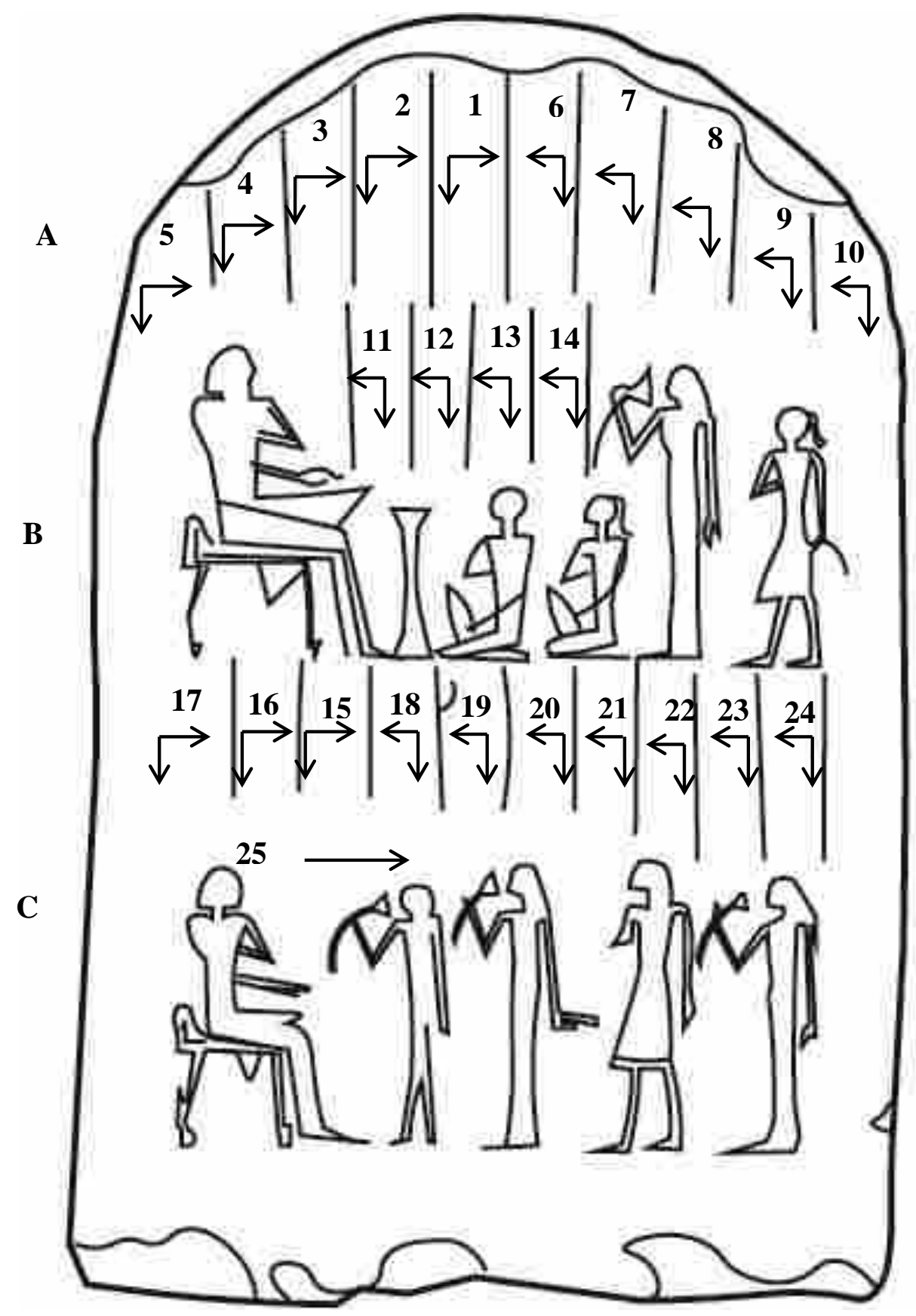

Fig. 1: Facsimile of The stela of Tjj C.G. 10232 without inscriptions

The second section contains the main scene where the upper register is occupied by a scene depicting the owner of the stela seated on a short back chair wearing a short kneeleaned kilt. He wearing a shoulder-length wig and it's common in the Middle Kingdom. His right hand is extended in front of him towards the altar and the left arm is shown on his chest. An altar for a libation with a pottery vessel is depicted in front of the owner of the stela. There are two seated sons behind the altar. His wife has depicted standing wears a long linen tunic behind the seated sons. She wears a long wig and smells a lotus flower in her right hand. The other hand is extended along her body. The wife is facing her husband, behind her is found the third son standing and he also facing his father. $\mathrm{He}$ wears a short kilt holding a lotus flower in his left hand and the right one is on his chest with his side lock of hair, in addition to four vertical lines which represent the name of 
his wife, and sons. The third section consists of ten vertical columns and one horizontal line. The scene depicts the owner's father seated on a short back chair wearing a short knee-length kilt. He wears a shoulder-length wig. His right hand is extended in front of him and the left arm is shown on his chest. The draftsman started to make a relief of an altar but he stopped because of the lack of space. There are some traces of his try but very faint. His wife, daughter, brother and a wife of his brother are standing facing him. His daughter is standing at the beginning of the line wearing a short tight tunic. She smells a lotus flower in her right hand. His wife is standing after his daughter wearing a long linen tunic. She smells a lotus flower also in her right hand. His brother is standing in the same line facing him. He wears a short knee-length kilt. He wears a shoulderlength wig. His right arm is held to his chest and his left arm extended along his body. The wife of his brother is standing behind him wearing a long linen tunic holding a lotus flower in her right hand. Her left hand is straight along her body. She wears along shoulder wig. In general, the stela is in a quiet fair state of preservation.

\section{INSCRIPTIONS}

\subsection{First section}

\subsubsection{The text on the left-oriented from right to left}

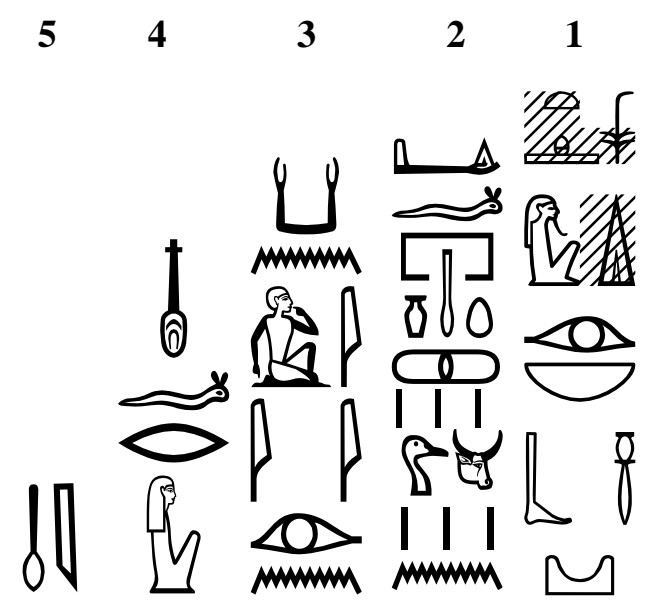

(1)<htp di> ${ }^{(\mathrm{a})} n s w^{(\mathrm{b})} W \operatorname{sir}^{(\mathrm{c})} n b 3 b \underline{d} w^{(\mathrm{d})}(2) d i . f p r t h r w t h n k t^{(\mathrm{e})} k 3 w 3 p d w^{(\mathrm{f})} n(3) k 3 n^{(\mathrm{g})} \operatorname{Ij} j^{(\mathrm{h})}$ ir.n (4) $n f r<t>^{(i)}$ (5) $m 3^{r}-h r w$

(1)<An offering which> the king < has given> to/and ${ }^{1}$ Osiris, lord of Abydos, (2)that may he gives ${ }^{2}$ an invocation offering of cattle and fowl (3)for the $k a$ of Ijj born of (4) $n f r<t>$, (5)true of voice.

\footnotetext{
${ }^{1}$ Satzinger, H., 'Beobachtungen zur Opferformel: Theorie and Praxis', in: LingAeg 5, (1997), 177-188; Franke, D., 'The Middle Kingdom offering formulas: A Challenge', in: JEA 89, (2003), 39-57; Stefanovic, D., 'The Late Middle Kingdom stela of the staff of provisioning sector ( $\check{s} n$ ') (Musées d'art et d'histoire, Genève 6875)', in: SAK 39, (2010), 314.

${ }^{2}$ Sometimes, it appeared without di.f formula: see Stefanovic, D., in: SAK 39, (2010), 314.
} 


\subsubsection{The text on the right hand oriented from left to right}

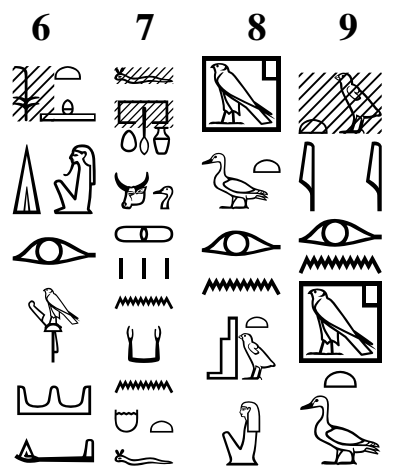

(1) htp di <nsw> Wsir <hnty> Imntyw ${ }^{(\mathrm{j})}$ di (2) <.f prt hrw >t hnkt k3w 3pdw nkJ n hmmt.f (3) $s 3 t h w t-h r^{(\mathrm{k})} i r . n 3 s t w^{(1)}(4)<t w>j(\mathrm{~m})$ ir.n s3t ḥwt-ḥr

(1) An offering which <the king> gives to/and Osiris, <foremost of > westerns that may $<$ he> gives (2) <an invocation offering> of bread, beer, cattle and fowl for the $k a$ of his wife (3) $s 3 t h w t-h r$, born of 3stw, (4) <tw $>j$, born of $s 3 t h w t-h r^{\prime \prime}$.

\subsection{Second section}

The inscription in four vertical columns oriented from left to right

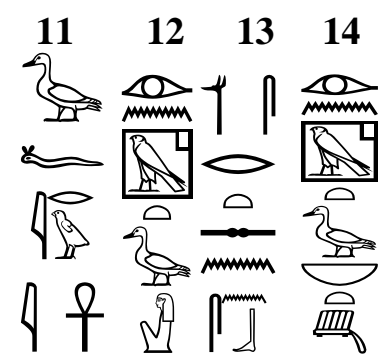

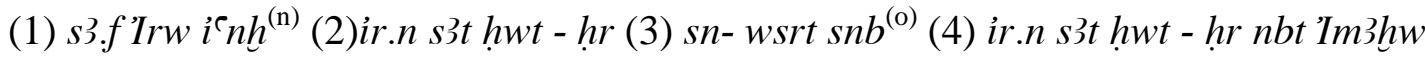

(1) His son 'Irw- i`nh, (2) born of s3t ḥwt- hrr, (3) (his son) sn- wsrt snb (4) born of $s 3 t$ $h w t$ - hr , lord of veneration.

\subsection{Third section}

The main inscription consists of ten vertical columns and one horizontal line.

\subsubsection{The hieroglyphic text over the owner's father is written in three columns from right to left.}

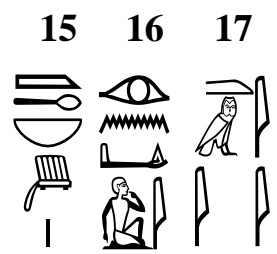

(1) $i m y^{(\mathrm{p})}$ (2) ir.ndi.. ${ }^{(\mathrm{q})}$ (3) $m 3^{c}$ hrw nb im3h

(1) imy, (2) born of di.i., (3) true of voice, lord of veneration. 


\subsubsection{The hieroglyphic text above his wife is written in seven columns from left to} right:

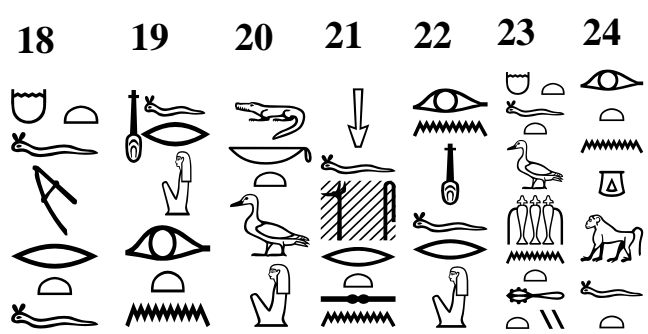

(1) hmt.f mrt.f (2)nfr $<t>$ irt.n (3)s3t $s b k^{(\mathrm{r})}$ (4)sn.f $s n-<w s>r t^{(\mathrm{s})}$ (5)ir.n $n f r<t>(6) h m t . f s 3 t$ hnty-hity ${ }^{(\mathrm{t})}(7)$ irt.n $g f t^{(\mathrm{u})}$

(1) His wife, his beloved, (2) $n f r<t>$, born of (3) $s 3 t-s b k$ (4) His brother, $s n-<w s>r t$, (5) born of $n f r t "$ (6) His wife s3t-hnty-hity, (7) born of gft".

\subsubsection{A horizontal hieroglyphic text over the daughter oriented from left to right:}

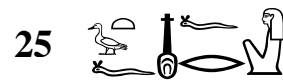

s3t.f $n f r<t>$

His daughter, $n f r<t>$

\section{COMMENT}

(a) htp di: is missing from the formula within the lunette.

(b) $<h t p d i>n s w$ : The orthography of this formula appeared in the order $s w$ with $t+h t p$ without phonetic complements. This form of writing occurred from the end of Twelfth Dynasty and was attested in the Thirteenth Dynasty with some alternations. ${ }^{1}$

(c) Wsir: the writing system of the name of Osiris is unfamiliar where there is switching of the order of signs between A40 and D4 to write them into the available space. The oldest mention of Osiris is in the Pyramid Texts as the king united with Osiris in the netherworld. ${ }^{2}$ Osiris took the role of the formerly god of the dead hnty imntt, the god of the netherworld who appeared in the presynaptic period as a couching jackal protecting Abydos necropolis. ${ }^{3}$

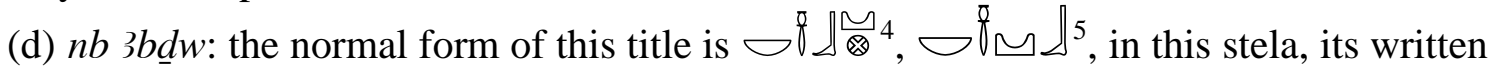
without the determinative niwt, this form widely appears in the Thirteenth Dynasty on

\footnotetext{
${ }^{1}$ See, Vernus, P., 'Sur les graphies de la formule "l'offrande que donne le roi" au Moyen Empire et à la Deuxième Période Intermédiaire', in: S. Quirke (ed.), Middle Kingdom Studies, New Malden, (1991), P.144-145; Marée, M., 'A Remarkable Group of Egyptian Stelae from the Second Intermediate Period', in: OMRO 73, (1993), 8-11; Selim, S., 'The Stela of $h r-w d \underline{d} 3 w$ in the Cairo Museum (JE 41332)', in: SAK 28, (2000), 247.

${ }^{2}$ Sethe, K., Altägyptische Pyramiden Text, 2 Bde, Leipzig, (1908), 214 (a-c).

${ }^{3}$ Saied, M., Götterglauben und Gottheiten in der Vorgeschichte und Frühzeit Ägyptens, Doktorarbeit, Kairo-Uni, (1997), 6-7; LGG, II, 532:568.

${ }^{4}$ Selim, S., in: $S A K 28,(2000), 254$.

${ }^{5}$ Abdel- Raziq, A., 'A Middle Kingdom funerary stela of a woman at Al-Salam School Museum, Assiut', in: JEA 99, (2013), 277.
} 
the Stele of ir-gmt.f, stele of snb, Stele of snbi. ${ }^{1}$ In the New Kingdom, sometimes it appears with more abbreviation $\backsim .^{2}$

(e) prt hrw $t$ hnkt: There is a new element to be observed in the offering formula of the early Middle Kingdom with the introduction of di.f. ${ }^{3}$ The only structural difference between Old Kingdom and Middle Kingdom formulas is the additional insertion of a prospective di.f "may he give", introducing the following request for an invocation offering. ${ }^{4}$ It is believed that Prt-hrw was introduced during the Eleventh Dynasty. However, the construction changed in the Twelfth Dynasty to di.f/.s/.sn. ${ }^{5}$

(f) $k 3 w 3 b d w$ : this elements appear on this stela with two different forms widely appeared during the Thirteenth Dynasty and continues in the Second Intermediate Period. ${ }^{6}$

(g) $n k 3 n$ :The occurrence of this phrase on stela is probably known from an earlier date despite claims by Bennett ${ }^{7}$ : although only later in the Dynasty did it make its way to the superstructure. ${ }^{8}$ Its occurrence on Stela is even later than the end of the Old Kingdom. ${ }^{9}$ Bennett suggests that $n k 3 n$ occurred since the time of "Amenemhat II", after the alternations happened to the formula since the time of "Senusert I". ${ }^{10}$ This form of writing did not occur before the $13^{\text {th }}$ Dynasty. ${ }^{11}$ There are several examples on the Thirteenth Dynasty stela mentioned the phrase $n k 3 n$ typically. ${ }^{12}$ These examples simply state that the monument's owner was the recipient of the offering.

(h) Ijj: Ranke ${ }^{13}$ Mentioned that this name appeared in the Middle Kingdom and continued in the Second Intermediate Period. It appeared with different forms 4 造 44,14

\footnotetext{
${ }^{1}$ Hein, I\& Satzinger, H., Stelen des Mittleren Riches I, Einschließlich Der 1 und II. Zfiischenzeit, Mainz, (1989), 39-43, 48-54, 56-61

${ }^{2}$ Clère, J., 'La Stèle de Sânkhptah, chambellan du roi Râhotep ', in: JEA 68, (1982), 66.

${ }^{3}$ The use of di.f (May he give ) appeared during the Twelfth Dynasty see: Orel, S., 'Two Unpublished Stelae from Beni Hasan', in: JEA 81, (1995), 218.

${ }^{4}$ Franke, D., in: JEA 89, (2003), 46; Obsomer, C., 'di. $f$ prt-hrw et la filiation $m s(t) . n / i r(t) . n$ comme critères de datation dans les textes du Moyen Empire', in: Cannuyer, C\& Kruchten. J.M (éds), Individu, sociéte et spiritualité dans l'Egypte Pharaonique et copte: Mélanges égyptologiques offerts au Professeur Artiside Théodoridès, Bruxelles, (1993), 192:196.

${ }^{5}$ Azam, L., 'An Unpublished Stela in the Egyptian Museum, Cairo, JE 88011', in: CASAE 37, (2008), 71; Bennett, C.J., 'Growth of the htp-di-nsw formula in the Middle Kingdom', in: JEA 27, (1941), 77; Lapp, G., 'Eine spezielle Opferformel des Mittleren Reiches', in: SAK 14, (1987), 181-183.

${ }^{6}$ Tomich, A., 'Changes in the htp-dj-nsw Formula in the Late Middle Kingdom and the Second Intermediate Period', in: Z̈̈S 138, (2011), 23.

${ }^{7}$ Bennett, C.J., in: JEA 27, (1941), 79:81.

${ }^{8}$ Barta, W., Aufbau und Bedeutung der altägyptischen Opferformel, $̈$ Ä 24, Glückstadt, (1968), 33, n.3.

${ }^{9}$ Abdalla, A., 'The Cenotaph of Sekwaskhet Family from Saqqara', in: JEA 78, (1992), Fig 2 (b).

${ }^{10}$ Bennett, in: JEA 27, (1941), 79 (N. 6).

${ }^{11}$ Pflüger, K., 'The private funerary Stelae of the Middle Kingdom and their importance for the study of Ancient Egyptian history', in: JOAS 67, (1947), 133.

${ }^{12}$ Cf. Stelae BM EA 215, EA 238, EA 252; Cairo CG 20089. Lapp, in: $S A K$ 14, (1987), 182.

${ }^{13}$ Ranke, $P N$, I, 7:17.

${ }^{14}$ Stela Cairo JE 52453(Davies, W. V., 'The tomb of a Governor of Elkab of the Second Intermediate Period ', in: Miniaci, G\& Grajetzki, W., The World of Middle Kingdom Egypt (2000-1550 BC): Contributions on archaeology, art, religion, and written sources, Vol II, London, (2016), 80 fig. 10); Stela Habachi, Heqaib, no. 90(Habachi, L., Elephantine IV. The Sanctuary of Heqaib. AV 33. Mainz, (1985), 105-106, pl. 184).
}

- 101 - Unpublished Stela of Ijj at Cairo Museum (C.G. 10232) 


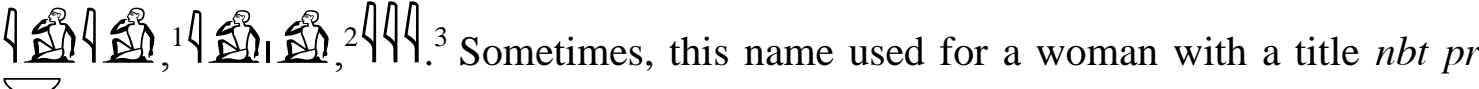
$\circ \sqsubset \neg .{ }^{4}$

(i) $n f r(t)$ : For this feminine name, Ranke, $P N$, I, 201:10.

(j) hnty Imntyw: it appears with a rare spelling. The scribe ignores hnty. ${ }^{5}$

(k) s3t hwt-hr: For this name see Ranke, PN 291,14.

(l) 3stw: see Ranke, PN I, 3. 18.

(m) $\langle t w>j$ : thy first part of the name are destroyed, but we can complete it by the remains where this name common during the Late Middle Kingdom. ${ }^{6}$

(n) irw i nhl: This name is not listed by Ranke, but maybe there are similar this name and $i r w^{7}$.

(o) sn- wsrt snb see Ranke, PN I, 269.6.

(p) imy: For this name see Ranke, PN I, 26.2. It appeared in other different forms as: A A4, 非 A4,

(q) di. i: This name is not listed by Ranke. Probably it represents the name $\approx A 4$ biw. ${ }^{10}$ (r)s3t sbk: see Ranke, PN I, 293.9

(s)sn-wsrt: see Ranke, PN I, 269.1

(t) s3t hnty-hty: the name hnty-hty widely appeared in the Late Middle kingdom for men $^{11}$, while $s 3 t$ hnty-hty is a common name during the Middle Kingdom with different

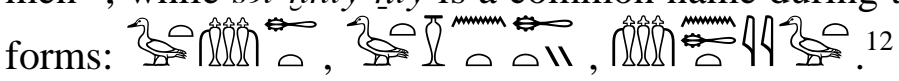

${ }^{1}$ Stela Durham DUROM.1964.186 (Smith, S., The Fortress of Buhen. The Inscriptions. EES, Excavation Memoir 48, London, (1976), 20-21, pl. VIII.1, LX.2).

${ }^{2}$ Statue base Cairo JE 87254(Davies, W. V., in: Miniaci, G\& Grajetzki, W., The World of Middle Kingdom Egypt (2000-1550 BC): Contributions on archaeology, art, religion, and written sources, Vol II, London, (2016), 74 n. 14, fig. 11-12).

${ }^{3}$ Cairo CG 20297 (Lange, H. O\& Schäfer, H., Grab- und Denksteine des Mittleren Reiches im Museum von Kairo. Vol. 1, Text zu No. 20001-20399. Catalogue général des antiquités égyptiennes du Musée du Caire, 5. Berlin, (1902), 310-311)

${ }^{4}$ Stela Cairo CG 20680 (Lange, H. O\& Schäfer, H., Grab- und Denksteine des Mittleren Reiches im Museum von Kairo. Vol. 4, Tafeln. Catalogue général des antiquités égyptiennes du Musée du Caire, 7, Berlin,(1902), pl. LI); Stela Hermitage 1080 (Bolshakov, O\& Quirke, S., The Middle Kingdom Stelae in the Hermitage. Publications interuniversitaires de recherches égyptologiques informatisées, vol. 3, Utrecht- Paris, (1999), no. 6); Stela Louvre C 314 (Ledrain, E., Les monuments égyptiens de la Bibliothèque Nationale (Cabinet des Médailles et Antiques), Vol. 1. Bibliothèque de l'École des Hautes Études, Sciemces phil. et hist. 38, Paris, (1879), pl. XIII).

${ }^{5}$ This word appeared with different forms as fổon

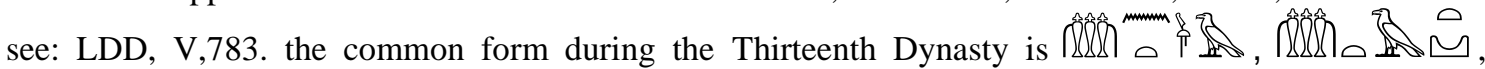

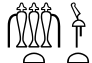

see: Hein, I\& Satzinger, H., Stelen des Mittleren Riches I, Einschließlich Der 1 und II. Zfiischenzeit, Mainz, (1989).

${ }^{6}$ Ranke, PN I, 379, 8.

${ }^{7}$ Ranke, PN I, 41.18; stela BM 1653= Tomich, A., From Workshop to Sanctuary: The Production of Late Middle Kingdom Memorial Stelae, Middle Kingdom Studies 6, London, (2017), pl. 14.

${ }^{8}$ Ranke, PN I, 26. 2.

${ }^{9}$ Stela BM 220 = Franke, D\& Maree, M., Egyptian Stelae in the British Museum from the 13th-17th Dynasties: Fascicule I, Descriptions, vol.1, London, (2013), 52-54, pl. 11.

${ }^{10}$ Ranke, PN I, 396, 6.

${ }^{11}$ Ewais, M., A., A social history of writing through hieratic sources of the Middle Kingdom from Ellahun, PhD Dissertation, Fayoum University, (2017), ;Rosati, G., 'A Rare Formula on A Thirteenth Dynasty Stela', in: Maree, M., The Second Intermediate Period (Thirteenth-Seventeenth Dynasties) Current Research, Future Prospects, OLA 192, Paris, (2010), 88.

${ }^{12}$ Ranke, PN I, 292.21 
(u) gf.t: see Ranke, PN I, 350.25.

\section{PALAEOGRAPHICAL REMARKS}

\begin{tabular}{|c|c|c|c|c|c|c|c|c|}
\hline Ser. & Sign & Forms & Ser. & Sign & \multicolumn{4}{|c|}{ Forms } \\
\hline 1 & 星 & $\begin{array}{cc}\text { 点 } \\
\text { R.1.3 }\end{array}$ & 5 & 8 & $\begin{array}{c}9 \\
\text { R.1.2 }\end{array}$ & $\begin{array}{c}9 \\
\text { R.1.7 }\end{array}$ & & \\
\hline 2 & 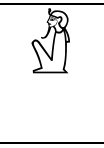 & $\underset{\text { R.1.6 }}{\rfloor}$ & 6 & ta & $\underset{\substack{f \\
\text { R. } 1.4}}{\operatorname{b}}$ & $\begin{array}{c}\text { T } \\
\text { R.3.8 }\end{array}$ & $\overbrace{\text { R.3.11 }}$ & \\
\hline 3 & $\sqcup$ & $\underset{R .1 .3}{L} \quad \sqcup$ & 7 & мимим & R.1.2 & $\begin{array}{l}\text { Mrs } \\
\text { R.2.3 }\end{array}$ & R.1.7. & R.1.9 \\
\hline 4 & EO & $\begin{array}{cc}0 & \emptyset \\
\text { R.1.2 } & \text { R.1.7 }\end{array}$ & 8 & 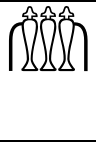 & $\begin{array}{l}\text { ती } \\
\text { R.3.6 }\end{array}$ & & & \\
\hline
\end{tabular}

1. $\frac{1}{\Delta}$ : The head is a dot, and the body appears as long vertical lines. The arms together have written with one single line.

2. $\rfloor$ : this sign appeared with two unfamiliar forms, the first one, the sign appears as a vertical line to represents the body and a short horizontal line for the base, the second with an oblique line may be to represent the beard.

3. the sign appears with a similar form of hieratic, ${ }^{1}$ with hands including thumbs.

4. $V$ : In general the sign appears without horns, sometimes the sign has an oval shape .

5.9 the neck is very long, and there is a part of the back.

6. T the vertical line above the crossbar disappeared, and sometimes all of this part is omitted. The lower part of the sign has a dot or an oval.

7. $M$ : this sign appears with different forms. The common form is a horizontal line with short strokes at both ends or at only one side. Sometimes it represents by a zigzag, the number of the waves is between four and eight. Fewer cases are a combination of the horizontal line and zigzag.

8. ता : it consists of three vertical lines, with a horizontal line on the top and another one with sort strokes at both ends in centre.

\section{GENEALOGY}

The stela provides information regarding the genealogy of the family up to three different generations. The three generations are depicted on this stela, while being indicated with words such as ir.n/ms.n, hmt.f, sn.f, s3.f s3t.f. Thus, the following matrix shows the relationship between the three generations.

${ }^{1}$ Möller, G., Hieratische Paläographi I, 10,108. 


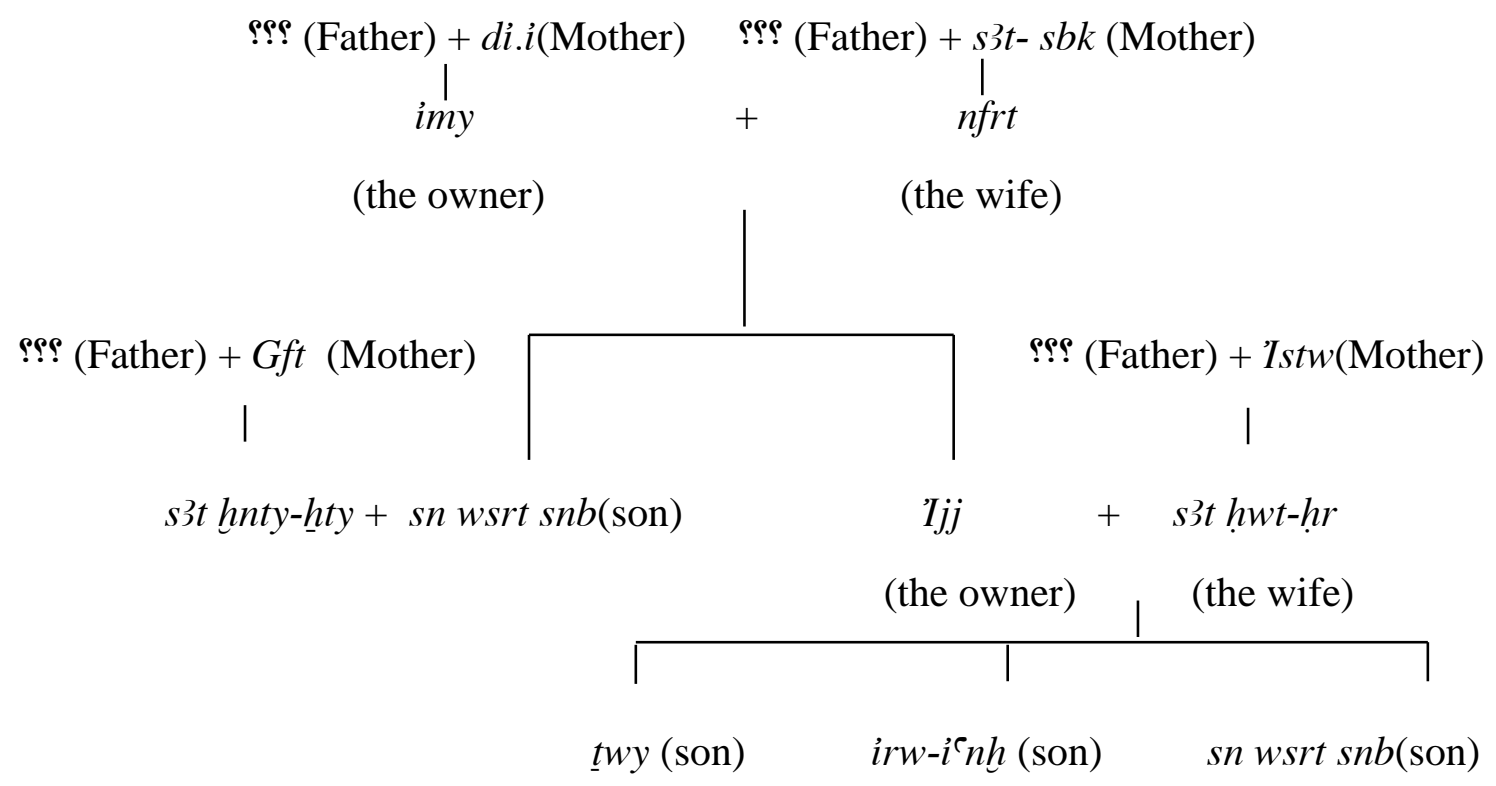

\section{DATING}

On the basis of stylists and artistic features, moreover, the linguistic and Palaeographical remarks mentioned above, the stela can be dated to the first half of the Thirteenth Dynasty.

The motif of smelling the lotus does not appear on dated stela earlier than Senusert I, when its rather frequently met with, but only in connection with women. ${ }^{1}$ Later it seems to become somewhat rare. From the time of Amenemhat II onwards, men too are represented as smelling the lotus. ${ }^{2}$ Women are depicted in Ancient Egyptian Scenes holding lotus flowers, a simple of life and resurrection ${ }^{3}$. Seats depicted on the stela appear with a high back and a scarf over it. This is a remarkable criterion of dating stela in the Thirteenth Dynasty. ${ }^{4}$

Palaeographical style of this stela also characterized the Thirteenth Dynasty. The previous table shows the similarity of the script between the stela under study and another Thirteenth Dynasty stela.

\footnotetext{
${ }^{1}$ Tomich, A., 'A twelfth dynasty stela workshop possibly from Saqqara', in: JEA 97, (2011), 117-126. ${ }^{2}$ Pflüger, K., in: JOAS 67, (1947), 130 [6].

${ }^{3}$ Fischer, H.G., 'A God and a General of the Oasis on a stela of the Late Middle Kingdom', in: JNES 16 no.4, (1957), 224; Harer, W.B., 'Lotus', in: D. Redford (ed.), The Oxford Encyclopedia of Ancient Egypt, Vol. II, AUC Press, (2001), 305. Harer, W.B., 'Pharmacological and biological properties of the Egyptian lotus', in: JARCE 22, (1985), 49.

${ }^{4}$ Compere with JE. 43461, 46784, CG. 20232, 454, 599; Scott, N., 'Our Egyptian Furinture', The Mertropolitan Museum of Art Bullitan, Vol.24, N.4, (1965), 140.
} 


\section{REFERENCES}

- Abdalla, A., 'The Cenotaph of Sekwaskhet Family from Saqqara', in: JEA 78, (1992), 93-111.

- Abdel- Raziq, A., 'A Middle Kingdom funerary stela of a women at Al-Salam School Museum, Assiut', in: JEA 99, (2013), 275-281.

- Azam, L., 'An Unpublished Stela in the Egyptian Museum, Cairo, JE 88011', in: CASAE 37, (2008), 71

- Barta, W., Aufbau und Bedeutung der altägyptischen Opferformel, ÄF 24, Glückstadt, (1968).

- Bennett, C.J., 'Growth of the Htp-di-nsw formula in the Middle Kingdom', in: JEA 27, (1941), 77-82.

- Bolshakov, O\& Quirke, S., The Middle Kingdom Stelae in the Hermitage. Publications interuniversitaires de recherches égyptologiques informatisées, vol. 3, Utrech- Paris, (1999).

- Clère, J., 'La Stèle de Sânkhptah, chambellan du roi Râḥotep' , in: JEA 68, (1982), 6068.

- Davies, W. V., 'The tomb of a Governor of Elkab of the Second Intermediate Period', in: Miniaci, M\& Grajetzki., The World of Middle Kingdom Egypt (2000-1550 BC): Contributions on archaeology, art, religion, and written sources, Vol II, London, (2016), 71-84.

- Ewais, M., A., A social history of writing through hieratic sources of the Middle Kingdom from El-lahun, PhD Dissertation, Fayoum University, (2017)

- Fischer, H.G., 'A God and a General of the Oasis on a stela of the Late Middle Kingdom', in: JNES 16 No.4, (1957), 223-235.

- Franke, D\& Maree, M., Egyptian Stelae in the British Museum from the 13th-17th Dynasties: Fascicule I, Descriptions, vol.1, London , (2013).

- Franke, D., 'The Middle Kingdom Offering Formula: A Challenge', in: JEA 89, (2003), 39-57.

- Habachi, L., Elephantine IV. The Sanctuary of Heqaib. AV 33. Mainz, (1985).

- Harer, W.B., 'Lotus', in: D. Redford (ed.), The Oxford Encyclopedia of Ancient Egypt, Vol. II, AUC Press, (2001), 305.

- _ 'Pharmacological and biological properties of the Egyptian lotus', in: JARCE 22, (1985), 49-54.

- Hein, I\& Satzinger, H., Stelen des Mittleren Riches I, Einschließlich Der 1 und II. Zfiischenzeit, Mainz, (1989).

- Lange, H. O\& Schäfer, H., Grab- und Denksteine des Mittleren Reiches im Museum von Kairo. Vol. 1, Text zu No. 20001-20399. Catalogue général des antiquités égyptiennes du Musée du Caire, 5. Berlin, (1902).

- _ Grab- und Denksteine des Mittleren Reiches im Museum von Kairo. Vol.

4, Tafeln. Catalogue général des antiquités égyptiennes du Musée du Caire, 7, Berlin,(1902)

- Lapp, G., 'Eine spezielle Opferformel des Mittleren Reiches', in: SAK 14, (1987), 181183.

- Ledrain, E., Les monuments égyptiens de la Bibliothèque Nationale (Cabinet des Médailles et Antiques), Vol. 1. Bibliothèque de l'École des Hautes Études, Sciemces phil. et hist. 38, Paris, (1879).

-Lesko, L., A dictionary of Late Egyptian, 5 vols, Berkeley, (1982-1990).

- Marée, M., 'A Remarkable Group of Egyptian Stelae from the Second Intermediate Period', in: OMRO 73 (1993), 8-11 
- Möller, G., Hieratische Paläographie, I, Leipzig, (1927).

- Obsomer, CL., 'di. f prt-xrw et la filiation ms(t).n/ir(t).n comme critères de datation dans les textes du Moyen Empire', in: Cannuyer, C\& Kruchten. J.M (éds), Individu, sociéte et spiritualité dans l'Egypte Pharaonique et copte: Mélanges égyptologiques offerts au Professeur Artiside Théodoridès, Bruxelles, (1993), 163-201.

- Orel, S., 'Two Unpublished Stelae from Beni Hasan', in: JEA 81, (1995), 216-220.

- Pflüger, K., 'The private funerary stelae of the Middle Kingdom and their importance for the study of Ancient Egyptian history', in: JOAS 67, (1947), 127-135.

- Ranke, H., Die ägyptischen Personennamen, vols I-III, Augustin: Glückstadt, (19351977).

- Rosati, G., 'A Rare Formula on A Thirteenth Dynasty Stela', in: Maree, M., The Second Intermediate Period (Thirteenth-Seventeenth Dynasties) Current Research, Future Prospects, OLA 192, Paris, (2010), 85-90.

- Saied, M., Götterglauben und Gottheiten in der Vorgeschichte und Frühzeit Ägyptens, Doktorarbeit, Kairo-Uni, (1997).

- Satzinger, H., 'Beobachtungen zur Opferformel: Theorie and Praxis', in: LingAeg 5, (1997), 177-188.

- Scott, N., 'Our Egyptian Furinture', The Mertropolitan Museum of Art Bullitan 24, N.4, (1965), 129-150.

- Selim, S., 'The Stela of Hr-wDAw in the Cairo Museum (JE 41332)', in: SAK 28, (2000), 243- 256.

- Sethe, K., Altägyptische Pyramiden Text, 2 Bde, Leipzig, (1908).

- Smith, S.,The Fortress of Buhen. The Inscriptions. EES, Excavation Memoir 48, London, (1976).

- Stefanovic, D., 'The Late Middle Kingdom stela of the staff of provisioning sector (Sna) (Musées d'art et d'histoire, Genève 6875) ', in: SAK 39, (2010), 313-319.

- Tomich, A., 'Changes in the Htp-dj-nsw Formula in the Late Middle Kingdom and the Second Intermediate Period', in: Z̈̈S 138, (2011), 20-34.

(2011), 117-126.

,'A twelfth dynasty stela workshop possibly from Saqqara', in: JEA 97,

- _ From Workshop to Sanctuary: The Production of Late Middle Kingdom

Memorial Stelae, Middle Kingdom Studies 6, London, (2017).

- Vernus, P., 'Sur les graphies de la formule "l'offrande que donne le roi" au Moyen Empire et à la Deuxième Période Intermédiaire', in: St. Quirke (éd.), Middle Kingdom Studies, New Malden, (1991), 141-152. 


\section{PLATES}

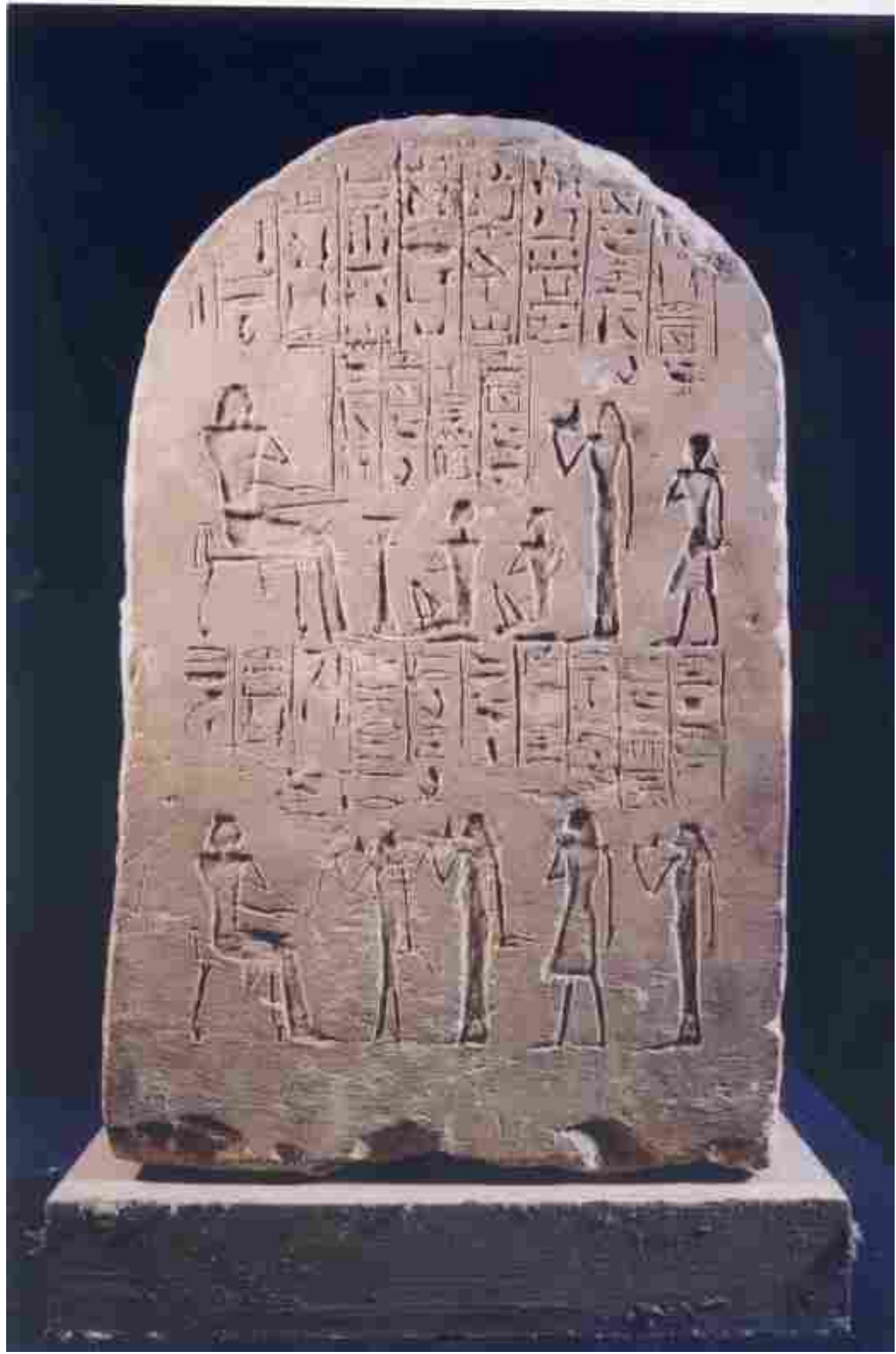

PI. 1: The stela of $1 j j$ C.G. 10232

Copyright: the Egyptian Museum at Cairo 


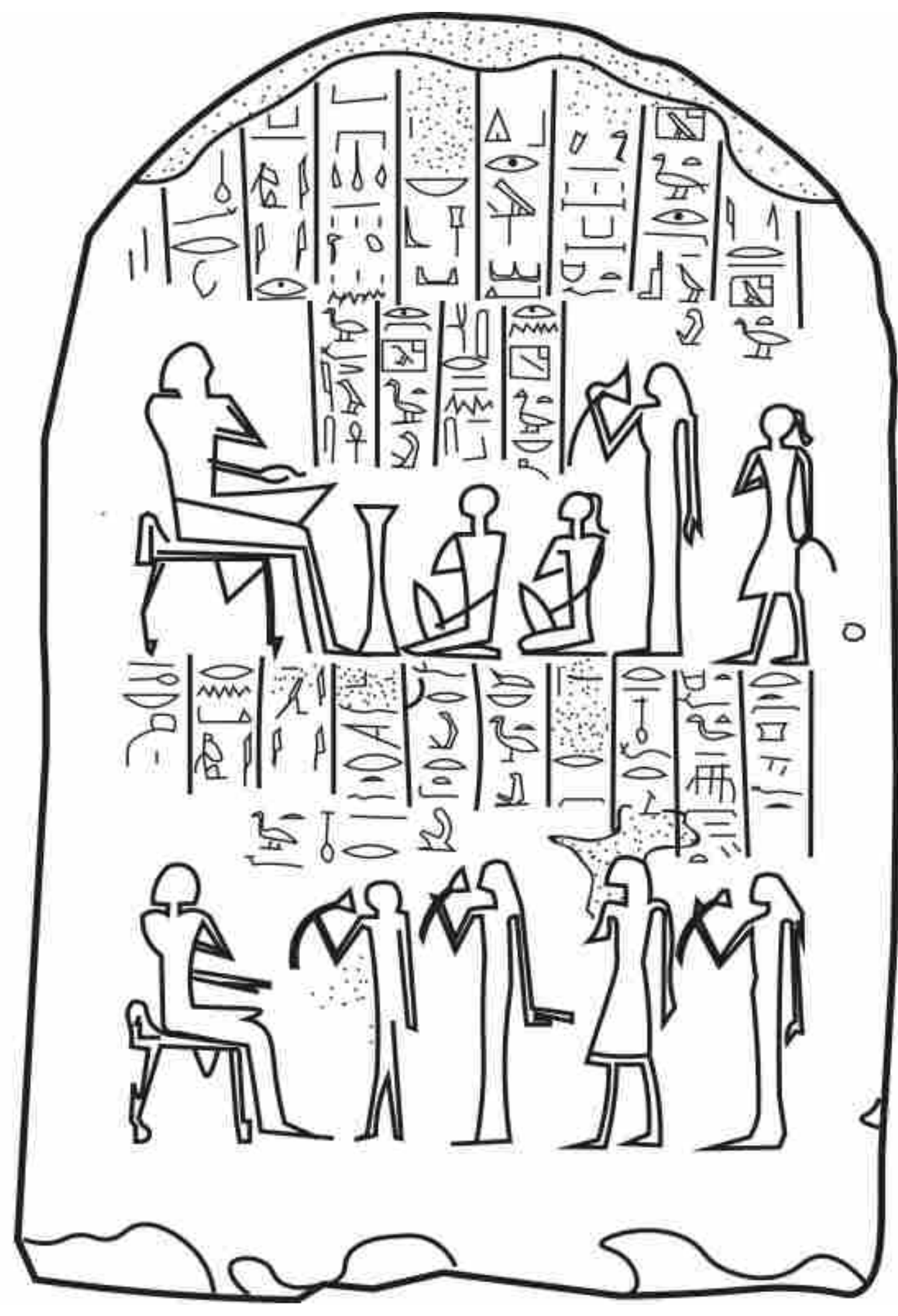

Pl.2: Facsimile of The stela of $1 j j$ C.G. 10232 